\title{
The Changing Role of Government
}

\author{
Shaoguang Wang \\ Department of Political Science \\ Yale University \\ New Haven, CT 06520 \\ USA \\ Tel: $203-432-5262$ \\ Tax: 203-432-6196 \\ Email: <shaoguang.wang@yale.edu> \\ Department of Government and Public Administration \\ The Chinese University of Hong Kong \\ Shatin, NT \\ HONG KONG \\ Tel: 852-2609-7515 \\ Fax: 852-2603-5229 \\ Email: <wangshaoguang@cuhk.edu.hk>
}

February 8, 2000 
What role should the state play in China's transition to a market economy? Accepting the neoclassic assumption of the naturalness, spontaneity, and efficacy of market, and public choice theorists' thesis of the state, some Chinese economists suggest that the role of the state should be restricted to providing defense, defining property rights, enacting and implementing a system of laws, enforcing contracts, and maintaining the value of

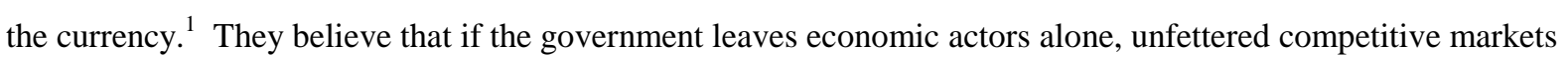
would work better in generating socially desirable outcomes.

In what follows, we argue that the state should play an active role in China's transition to a market economy. The argument is built upon three observations. First, even in mature market economies, state interventions are indispensable for remedying market irrationalities and for organizing efficient markets. Second, market institutions cannot be properly installed without the support of the state. Especially, if China is to establish a "socialist market economy," the state has the obligation to mitigate the hardships and the cruelties caused by the market transition. Third, as a giant developing country, China faces many challenges, which cannot be settled through voluntary transactions.

\section{The Roles of the State in Mature Market Economies}

In the West, economists often use the theory of market failure found in welfare economics as a rationale for government activity. Market failures here refer to situations in which voluntary transactions do not result in allocative efficiency. Many sources of market failure have been recognized in standard economics textbooks:

Public goods Characterized by their broad use, indivisibility, and nonexcludability, "public goods" cannot be provided for through the market system, i.e., by transactions between individual consumers and producers. A classic example is national defense, which has to be provided by the state.

Infrastructure has some properties of public good. An economy is unlikely to take off unless its infrastructure is sound. Due to the presence of indivisibility, however, private investors may find the provision of infrastructure not profitable, at least in the short-run. That is why infrastructure is financed by governments in most countries.

Macroeconomics stabilization may also be considered a "public good." Market economies have always been characterized by fluctuations in the business cycle, by periods of boom and bust. Economic stability thus is 
obviously something desirable, for it benefits all. But precisely for this reason, few have incentives to make contribution to its realization. The government therefore has to bear the responsibility of maintaining macroeconomic stability.

Externalities Externalities occur when there is divergence between private and social costs or benefits. Wherever externalities exist, the actions of an economic agent (individual or firm) impose costs upon, or provide benefits to, third parties who are unlikely to receive compensation, or to be charged, through markets for what they get involuntarily. The result could be either too little or too much production or consumption. Some suggest that it is possible for people to voluntarily get together to solve the problem of externalities. If the number of third parties is large, however, the transaction costs for all those involved to negotiate a solution tend to be prohibitively high. Moreover, externalities always exist and at any given moment there may be many kinds of externalities coexisting at once. Thus, if the state does not come to the fore to internalize them, a great deal of people's time and resources would be wasted in endless rounds of unproductive negotiation.

Increasing Returns Where economic activities are subject to increasing returns (and/or decreasing marginal costs), a free market will result in monopoly. Facing no competition, a profit maximizing monopolist will sell a lower output and charge a higher price than it would pertain under competition. The outcome thus will be inefficient. A recent development in economics--the theory of "contestable markets"--suggests that as long as there are potential entrants, the production of a good or provision of a service by a monopolist does not necessarily signify that he will be able to exploit monopoly power. ${ }^{\text {日 }}$ What are ignored in the theory are sunk costs. In the modern time, there is hardly any industry the entry to which does not involve sunk costs. As a matter of fact, such costs are often very high. Substantial sunk costs are an effective barrier to entry. Thus, monopolists are unlikely to be disciplined by the potential entry of competitors. In other words, government anti-trust policy is still necessary.

Unemployment The competitive equilibrium model predicts full employment. However, due to downward rigidity of interest rates and nominal wages, the signaling mechanism in the capital and labor markets does not work in the ways neoclassic economists predict. As a result, high unemployment of workers and machines has often plagued capitalist economies. Although most economists do not treat unemployment as a market failure in its own right, but a consequence of some other market failures, some economists believe that "high unemployment is the most dramatic and most convincing evidence of market failure." 
$\underline{\text { Incomplete Markets }}$ The neoclassic model maintains that competitive markets can ensure economic efficiency, because it assumes that there are a complete set of markets. But, that is not the case in reality. Private risk and future markets, for example, are far from adequate. Markets do not exist for many possible future contingencies and many of the important risks that we face are uninsurable. Incomplete risk markets may lead to inefficient levels of investment. Moreover, prices cannot serve the function of coordinating decisions concerning the composition of capital formation without a complete set of future markets.

In the absence of a complete set of future and risk markets, each economic agent needs a model of the whole economy in order to make future-oriented decisions (like entry and exit). Without formulating expectations about the behavior of other agents, his or her decisions can hardly be considered rational. If s/he does, however, s/he is in effect using as much information as would be required for a central planner. In such a conceptualization of economic behavior, as Arrow remarks, "the superiority of market over centralized planning disappears."

Information Failure Information has two special features: Once information is produced, it cannot be destroyed; and giving it to one more individual does not detract from the amount others have. Efficiency requires that information be made accessible to all who want it. However, private producers of information have interest in keeping it for their own exclusive consumption. For this reason, the private market is unlikely to provide an adequate supply of information. ${ }^{0}$ This is true especially when information can be used to further an agent's own welfare or where acquiring and transmitting information is costly. The government could play a part in remedying information failures. Given the asymmetric distribution of information between the consumer and the producer, for instance, the state may use regulations to protect former's interests. In addition, the state may offset externalities in the area of information by collecting, processing, and disseminating crucial information (e.g. information about foreign markets) to those who need it in the national economy.

While the traditional literature assumes that markets are efficient except for some well defined market failures, more recent studies reverse the presumption: it is only under exceptional circumstances that markets are efficient. Greenwald and Stiglitz show that whenever markets are incomplete and/or information is imperfect (which are true in virtually all economies), even competitive market allocation is not constrained Pareto efficient. In other words, there almost always exist schemes of government intervention that can induce Pareto superior outcomes, thus making every one better off. ${ }^{0}$ Although the pervasiveness of market failures doesn't warrant the 
state in thrusting its nose into everything, the "optimal" range of government interventions is definitely much larger than the traditional "market failure" school recognizes.

Even if a competitive market might generate a Pareto-efficient allocation of resources, there are still the cases for government action, because an efficient allocation of resources might entail great inequality. According to the Second Theorem of Welfare Economics, for any Pareto-efficient allocation, there exists a set of prices that support that allocation as a market equilibrium, but each with a different distribution of welfare. The problem is to decide which Pareto-efficient allocation conforms to society's notion of distributive justice.

Obviously, the market cannot do it. The social welfare function is simply not a market construct; it must evolve from the political process.

Moreover, the Pareto principle can be pushed a step further to allow economic efficiency to encompass not just actual Pareto improvement, but also potential Pareto improvements. These are changes in which some persons gain while others lose, but in which there are overall net gains in the sense that the gainers hypothetically could compensate the losers and still be better off. The problem is that in the "spontaneous order" advocated by neoclassic economists there is no way to ensure that the gainers would compensate the losers. ${ }^{\square}$ Without institutionalized mechanisms to redistribute income, market forces thus tend to expose individuals to aggregate effects that expand the fortunes of some while reducing the fortunes of others.

Most people think it right to alter the distribution of income in helping the poor or in improving equity. But inequality is not just morally repulsive. Numerous studies have shown that economies in which wealth is

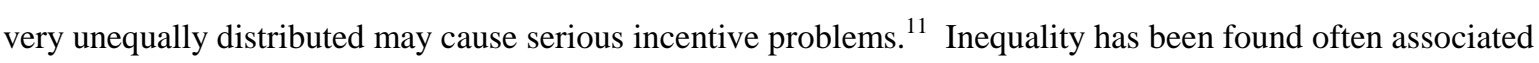
with slower growth.

More important, the survival of a market economy may to a great extent depend upon social equity. If asymmetric rewards and punishments generated by market forces persist, and no adjustments through redistribution take place, then the gap between those who flourish and those who stagnate would continuously widen. As a result, social conflict may become intense and violence may begin to emerge. To contain the level of social disturbance below the suicidal destructiveness of national revolution, the market system must be embedded in a framework of institutions that provides for its own modification in response to social-economic pressures. Thanks to socialists' efforts and pressures from the working poor in the second half of the nineteenth century and a large part of this century, mechanisms of sharing the benefits of growth more equally have been to various degrees established in all advanced capitalist countries, which have helped to diffuse opposition against 
the market system. "If this lesson is not learned, if the appropriate instruments of state are not created, the preconditions of socialism will be recreated and the history of the nineteenth and early twentieth centuries will be repeated."

\section{The Roles of the State in Market Transition}

China is in the process of transition from a command economy to a market economy. In the course of transition, the market by definition should be established as the central mechanism of resource allocation and the role of the state in the economy redefined. The redefinition involves two major changes. First, the range of state intervention should be narrowed. Particularly, microeconomic decisions should be left to individual economic agents. Second, policy instruments need to be changed. Rather than relying on administrative commands, the government should try to affect production activity mainly through fiscal, monetary, and regulatory policies.

In the meantime, however, it should be avoided to view the market merely as a negation, that is, the absence of state intervention. Accepting Adam Smith's thesis that the natural human propensity to "truck, barter, and exchange" would automatically lead to market exchange, some people believe that once the stifling state is knocked out of economic realm, "market forces" would emerge full blown to put human society in perfect order. Such a blind belief in the naturalness, spontaneity, and efficacy of the market is probably one of the most dangerous illusions for market reformers. An effective government in fact is a precondition of transition to market economy. There are three reasons.

First, voluntary transactions cannot take place in an institutional vacuum.

A market economy cannot exist without effective legal, administrative, regulatory, and extractive institutions maintained by the state. Institutions are needed to perform, at a minimum, the following functions:

- $\quad$ to define property rights;

- $\quad$ to enact a system of laws;

- $\quad$ to enforce contracts;

- to collect taxes;

- $\quad$ to oversee banks;

- $\quad$ to supervise corporate entities;

- $\quad$ to promote and preserve competition; 
- to supply entrepreneurs with information that reduces uncertainty, cuts transaction costs, and secures private sector confidence in making investment decisions;

- to dislodge and then prevent the reemergence of subnational barriers

to free factor mobility;

- to facilitate communication and consultation with the private sector, labor organizations, and other important interest groups;

- to conduct strategic planning and macroeconomic analysis;

- to administer social security system;

- to provide the legal context within which disputes between competing economic agents are resolved;

- to ensure that groups capable of sabotaging the expansion of markets are not excluded from the political process.

Those institutions provide stability, certainty, and predictability necessary for facilitating efficient economic transactions. Historically, the creation of national markets coincided with the constitution and expansion of such state institutions in the West. Late developers in the Third World often failed to create functioning market systems and thereby resorted to interventionist regimes not because their governments were too "strong" but rather because their governments were too "weak." A weak state could be very intrusive, but at the same time lack the capacity to construct effective legal and regulatory institutions. ${ }^{4}$ 'There is evidence that under conditions of administrative weakness it is harder to create and regulate functioning national markets in

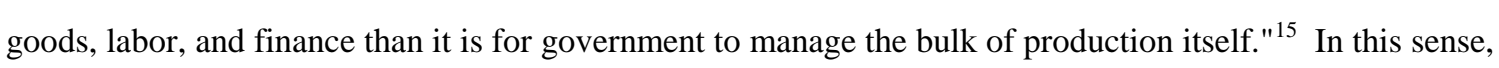
simply "shrinking the state" will not produce efficient market systems. To create competitive markets, new state institutions must be established and strengthened to perform the task of indirect regulation and administration, which is much more delicate and difficult than direct control.

Second, market institutions cannot spring up automatically. Some people believe that market institutions would spontaneously emerge from voluntary transactions between economic agents if the state stands aside. This has never happened before and we have no reason to believe that it is going to happen now.

Market institutions, in a sense, represent the essential, irreducible minimum of "public goods" that must be provided if markets are going to work at all. ${ }^{16}$ Since they are public goods, people are unlikely to cooperate voluntarily with one another to provide them, just as they would not in regard with the provision of other kinds of public goods. Of course, if the state does not provide market institutions, private economic agents would have to develop some informal rules to stem uncertainty and introduce some level of predictability into commercial 
transactions. In the absence of state intervention, however, these agreements are likely to evolve into pacts that neglect the interests of consumers and small producers and reflect only the preferences of those who possess economic power. Thus, as "public goods," market institutions initially have to be brought about by noneconomic forces. Even after the establishment of market institutions, the state still cannot stand aside. Individuals have incentives to break market rules--to corrupt the legal basis of market exchange, to collude in anti-competitive ways, to misrepresent the nature of assets which are the subject of contracts, and so on. Enforcement costs of market-conforming behavior can be extremely high. In countries where there is already cultural and ideological support for self-restraint in maintaining the rules of the marketplace, enforcement costs of market-conforming behavior would be lower. In countries where the market economy is still in the making, however, enforcement of the rules would be more expensive, which can be performed only by a strong state. 17

Third, the market transition is not a consensual but a conflictual process.

The market economy is not just embedded in state institutions, it also has its ideological and moral basis, which is what the economy in the transition is lacking. Neoclassic economists' transhistoric assumption about the human motivation may enable them to generate sophisticated models, but the simple fact is, as Leiberstein points out, people's behavior has often been influenced by "habits, conventions, work ethics, partial calculation, and inertia." 18 When a great institutional change occurs, they often find it hard to adapt. In the case of market transition, people would not accept market values and behave according to market rules simply because the government has announced that their country has adopted the model of market economy. It took a long time for European countries to develop attitudes favorable to the formation of market systems in the eighteenth and nineteenth centuries, because, violating the "moral economy" that had preexisted the market economy, practices most consistent with market rationality caused a great deal of confusion and disturbance in those societies.

The state socialist system in a sense was also a moral economy characterized by what Chinese call "iron rice bowl" (lifetime employment) and "everyone eating from the same pot" (equal income distribution regardless of effort). To create a market economy, the "moral economy" has to be destroyed and a new ethic has to be cultivated or imposed, which is bound to trigger off protests against the logic of the market. Market development thus requires an ongoing process of "legitimization" supported by ideological indoctrination and even the armor of coercion. 
Moreover, the market transition involves not only the transformation of norms and values but also the redistribution of resources and power. The transition may provide some social groups with opportunities of upward mobility, deprive others of traditional privileges, and threaten the livelihood of still others. The transition is also likely to create inequalities in income and wealth that do not match existing patterns of entitlements, status, and power. In one word, the transition tends to dislocate groups in both the political and the economic realms, which would inevitably give rise to social conflicts and political struggle. ${ }^{0}$ The creation of market economy in England, for instance, was by not means a continuous and consensual process. Rather, it was a product of power struggle among social groups attempting to shape exchange relations in their interests.

In former state socialist countries' transitions to market economy, as many studies have predicted, "whatever their long-term consequences, in the short-run reforms are likely to cause inflation, unemployment, and resource misallocation as well as to generate volatile changes of relative incomes." ${ }^{2}$ Even in the best scenario, as in China, where initially everybody benefited from reforms, the situation seems to have turned from a positive-sum game into a zero-sum game by the mid-1990s: some people are gaining at the expense of others. The government of course can use its coercive power to impose the costs on certain disadvantaged social groups. In order to have a relatively smooth transition, however, it is better for the state to adopt measures alleviating transition pains by establishing new "safety nets" and somehow compensating those whose interests are threatened by the reform. This is a very expensive undertaking. The state has to be strong enough to amass sufficient resources for redistribution.

In his classic study of the rise of the market economy in England, Polanyi finds that the origin of market society is not "traceable to the mere desire of individual to truck, barter, and exchange." Instead, he believes the very idea that human beings have a natural propensity to 'truck, barter, and exchange' was a product of market society; not the other way around. Since the market is not a natural and necessary manifestation of human nature, one should not expect the development of a market economy to be a spontaneous process. In the case of England, Polanyi finds that "the road to the free market was opened and kept open by an enormous increase in continuous, centrally organized and controlled interventionism." 33 Governments also provided dynamics in transforming other European countries into market societies. If there was nothing natural or automatic about the rise of market mechanisms in early developers, if "markets," as Chaudhry points out, "are conscious constructs in the same vein that command economies are deliberate arrangements," 
everywhere a strong state is required to enforce the rules, norms, and institutions that are necessary for establishing a functioning market economy.

\section{The Roles of the State in Economic Development}

China needs not only to reform its system but also to develop its economy. In fact, development is the purpose of reform. What role should the government of a poor country play in its economic development? The market failure arguments imply that market economies are all the same and that a theoretically optimal boundary between the market and the state can be found. But this is apparently a wrong assumption. Embedded in different structural situations with respect to the level of development, geographic location, the size of country, culture, and international environment, different economies have to deal with different kinds and different degrees of market failure, which requires them to devise different institutions to overcome obstacles to their development. In other words, there does not exist a common model of state intervention that can solve market failure problems for all countries and at all times.

More specifically, we have reason to believe that markets may work less well in underdeveloped than in developed countries and that markets may work less well for underdeveloped than for developed countries.

Structural rigidities are the main reason why markets may work less well in underdeveloped than in developed countries. For a market economy to function efficiency, the three components of the price mechanism--signaling, response, and mobility--all have to work properly. ${ }^{25}$ First, prices must be elastic in signaling changes in demand and supply conditions. Second, economic agents--producers, consumers, workers, and owners of factors of production--must be willing and able to respond to market signals. Third, factors must be able to move readily and easily. But, in practice, those conditions of market equilibrium are often lacking in underdeveloped countries. Prices, for instance, are often distorted by monopoly. Even if we assume that prices are right, responses may be inadequate and factors immobile.

Four problems may cause inadequate responses to market signals. First, influenced by traditional values, habits, conventions, work ethics, and inertia, people in underdeveloped countries may not seek to "maximize" their own material well-being as neoclassic theories posit. Second, information crucial for making rational decisions is often hard to come by in underdeveloped countries. For instance, local farmers may not know price changes occurring somewhere else in the province, the country, or in the world. As a result, there is 
no way for them to construct complete inventories of all the available and prospective alternatives relevant to their objectives. Third, due to low level of education, even if economic actors in underdeveloped countries are willing to respond to market signals promptly and all relevant information is available, they may lack the ability of making rational decisions. For instance, they may not possess the cognitive and computational ability to compare alternatives, or, when facing uncertainty, they may not be able to estimate the relevant probability distributions and rate of discount. Thus, the alternative they select may be far less than optimum. Fourth, the downward rigidity of interest rates and nominal wages is just as strong in underdeveloped as in developed economies, especially in those countries where populism prevails.

For those reasons, in a good many times, the responses to market signals are lagged, inadequate, or even perverse in underdeveloped countries.

Deficient infrastructure, bottlenecks, poor management, and other structural and organizational constraints can further thwart the "spontaneity" of the market mechanism. Due to those characteristic features of underdevelopment, factors of production are often immobile, unable to move quickly, or able to move but only at high cost. ${ }^{26}$ High transport costs, for instance, may make sale of product in the market uneconomic. The lack of mobility of resources, or more precisely, the inability of some of the productive sectors to adjust timely to changes in demand thus make price mechanism less trustworthy.

Leibenstein envisages the economy as a "network of nodes and pathways." According to him, in this network, "the nodes represent industries or households that receive inputs (or consumer goods) along the pathways and send outputs (final goods or inputs for the other commodities) to the other nodes. The perfect competition model would be represented by a net that is complete; one that has pathways that are well marked and well defined, and in which each node deals with every other node on equal terms for the same commodity." If the above analyses are sound, then in the underdeveloped economy net, some of the nodes are hypoplastic, some of the pathways are clogged, and some portions of the economy are isolated from the others. In one word, this is a net which are full of "holes" and "tears, "27 which may justify more government actions in underdeveloped than in developed economies.

Even if markets work as well in underdeveloped as in developed countries, they may still work less well for underdeveloped than for developed countries.

According to the neoclassic economic theory, the market is good at achieving Pareto efficiency. But the notion of Pareto efficiency essentially is a static one, which concerns only about the allocative efficiency of 
given resources. However, static efficiency should not be the only, or even the chief, criterion for judging the performance of economic systems. Especially, from the standpoint of underdeveloped countries, dynamic value creation is far more important than static value allocation. As Suhartono, an Indonesian economist, points out:

The context of the problem facing the developing countries is fundamentally different from that addresses by static analysis: it is not one of merely adjusting the allocation of given resources more efficiently, but rather it is a question of how to accelerate economic and social development... In economic terms, the problem involves an expansion in the production possibility frontier, not only a movement along it, through increasing productive capacities and through the productive employment of unutilized or underutilized factors of production. Since from the point of view of the developing countries the analysis for static gains addresses itself to the wrong question, it is not of particular relevance.

Not only is allocative efficiency less relevant in developing countries, concern with it may also stand in the way of obtaining dynamic efficiency. Schumpeter contrasts an economy that optimizes subjects to given constraints with an economy that develops its productive capabilities:

Since we are dealing with a process where every element takes considerable time in revealing its true features and ultimate effects, there is no point in appraising the performance of the process ex visa of a given point of time; we must judge its performance over time, as it unfolds through decades or centuries. A system--any system, economic or other--that at every given point of time fully utilizes its possibilities to the best advantage may yet in the long run be inferior to a system that does so at no given point of time, because the latter's failure to do so may be a condition for the level or speed of long-run performance.

Long-run development involves many "big" industrial decisions that cannot automatically flow from decentralized, optimal decision making in the short run. ${ }^{0}$ Since markets work only incrementally, the elasticity of supply and demand therefore is larger in the long run than in the short-run. Thus, at best, the market can provide adequate signals only for marginal changes. If large changes have to be brought about in a short time, 
the price mechanism cannot be relied upon to induce the resources transfer necessary for such changes. Public interventions therefore are required both to invest directly to break critical bottlenecks and to nourish wholesome macroeconomic environment that encourages investment innovation from the private sector. $\frac{1}{3}$

To prepare economic take-off, underdeveloped countries first have to build up a solid infrastructure and alleviate bottlenecks that are creating disincentives to investment. Without a solid infrastructure in place, the costs of private entrepreneurial activities would be very high, which would clearly hamper industrialization. There is little dispute that, as a public good, the infrastructure has to be provided by the government. As a matter of fact, state and local governments made sizable direct investments in infrastructure projects in the early economic development of the United States.

Motivated by "a passionate desire to organize and hasten the process of catching up," the state should probably also play a major role in planning and financing key investments of the economy. Typically, capitals in underdeveloped economies are scarce and diffused, especially in the early years of industrialization. Moreover, with the desire to jump into the modern industrial sectors, those countries may want to use production technologies that require capital investments in excess of what individual investors are capable of amassing. Private entrepreneurs thus may not have the capacity to invest and innovate, even if they have the will. ${ }^{3.3}$ When they have the capacity, however, they may lack the will to do so, for two reasons.

First, the returns to some prospective socially desirable or necessary investments (including R\&D) may be too long term and uncertain for private firms to undertake by themselves. ${ }^{34}$ Since the markets that are necessary for such investments to be efficiently allocated do not exist, private firms may lack the willingness to assume the risks. Managers of private firms often face intense pressure for short-run returns. Thus they may be very myopia about the future and highly oriented to maximizing short-run profits. Frequently, private firms, ex ante, estimate private rates of return to long-run investments as too low, even though, ex post, private and social returns would be very high. As a result, investments may be socially suboptimal.

Second, large investments are often externality-intensive. An investment project could create opportunities for others elsewhere. For instance, such activities may enable industries downstream to take advantage of scale economies through production expansion, or induce greater specialization among firms. It is commonly accepted that investments in human capital and R\&D are essential to economic development. But, positive externalities arising from such investments tend to weaken private profit-making firms' incentive to 
engage themselves in those areas, even though they may pay over time, both privately and socially. ${ }^{3.5}$ Individual investors' profit and loss calculus simply could not adequately capture such social benefits.

If investment and innovation are the two wheels of development, the above analyses show that the invisible hand is not adequate in guiding an economy on those two dimensions. State interventions may be needed to help the economy to achieve its full potential. By supporting the development of education, financial systems, communications networks, and other forms of physical and institutional infrastructure, the state can help private enterprises to employ their productive resources at lower unit costs or reap higher prices for their

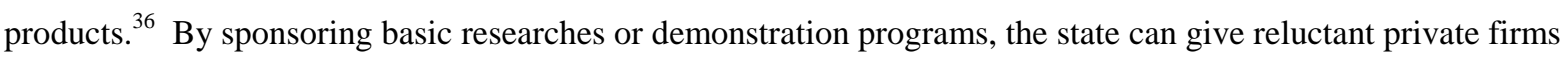
incentives to undertake their own R\&D projects. The state may also invest in building up nationwide information networks that keep track of emerging information in various industries relevant to other industries and disseminate such information. By providing missing information linkages between industries, the state can fill information gaps that impede innovation in production.

Of course, no government has a bottomless packet. Therefore, resources at the government's disposal need to be used wisely. Historically, no country has entered into modern economic growth without strategic targeting. Strategic targeting is necessary not only because capitals and talents available to the government of a country are always limited, but, more important, because there is evidence that the market alone cannot promote a right structural composition of industries compatible with the strategic goals of the nation. By employing various policy tools to adjust the industrial structure, the state can use its limited resources to stimulate particular lines of economic endeavor and make its economy internationally competitive.

Industrial intervention in the United States during the nineteenth century was huge. The government then targeted railroads and farmers with land give-away. It also played an important role in protecting the home market to permit business organizations to develop and utilize their productive resources to the point where they could attain competitive advantage in open international competition. In the United States, the strong protectionism did not recede until after W.W.II.

The Japanese State has gone much further. It has played an important role in preserving the home market for Japanese firms. It has sought to limit the number of enterprise competing in major manufacturing industries, thus creating incentives for existing companies to incur the high fixed costs necessary to attain competitive advantage. It has made efforts to shape the perception of producers and traders, leading them to hitherto unforeseen possibilities. It has promoted cooperative research and development among major Japanese 
competitors. It has ensured manufacturing corporations access to inexpensive finance. And the Japanese State has also provided industry with a highly educated labor force to fill blue-collar, white-collar, and managerial positions. Without those "disequilibrating" initiatives of the state, Japan's transformation from a backward economy into a heavy-weight player on international markets might have to take a much longer time, if possible at all.

During the late 1970s and the early 1980s, neoclassic economists often praised the East Asian Newly Industrializing Economies (NIEs) as models of laissez-faire. Closer analysis, however, reveals the guiding hand of "strong state" in Japanese fashion in those economies (Hong Kong is an exception). In East Asia, rather than relying upon the market to shape the composition of industries, the governments have played a significant role in determining which sectors or industries are more important for the future growth of the economies than others. Moreover, they have tried to divert resources to targeted industries and firms through complex import controls,

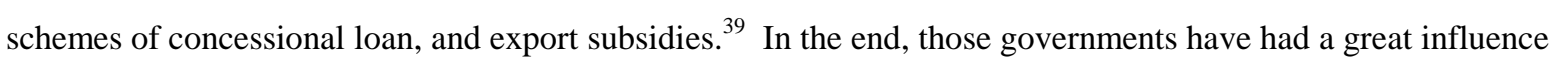
upon the course and pace of industrialization and upon the evolving structure of the domestic economies. Some ideologues have put the blame on active state intervention for the current crisis in East Asia. But, "the basic facts remain: no other region in the world has ever had incomes rise so dramatically and seen so many people move out of poverty in such a short time."

The cases of the United States, Japan and the East Asian NIEs illustrate that industrialization does not flourish in a fully free-market regime. Their cases also show that a country's comparative advantages are not always naturally endowed. Instead, they can be created if right industries are targeted and right policies applied to strengthen their international competitiveness. that are currently constructing market economies, because the "market" that they are "transiting" to is a truly global one, which is dominated by mammoth multinational corporations. To make its economy internationally competitive, a late developer needs a national strategy to give privileged access to public resources to those national business organizations that can best develop and utilize these resources. At the same time, however, it should prevent those organizations from turning into inefficient geriatric "rent-seeking" lobbies. Only a strong state that is relatively autonomous from the influences of domestic and foreign special interests can undertake such a dual task. 
State capacity is a concept concerning the effectiveness rather than the extensiveness of government intervention. A system that is intrusive and repressive is not necessarily effective. A functioning market system must be supported by an effective government. For a government to be effective, however, it has to be fiscally viable. Indeed, the extraction of fiscal resources is a precondition for the state to perform any of its roles discussed above. It is self-explanatory that public financing is required for the provision of collective goods and services, the redistribution of income, and public investment. To be operative, macroeconomic stabilization as well has to be conjoined by various fiscal policies, which could be costly. For countries that are in the process of market transition, there are also extra transitional costs. It is unlikely that the transition to market economy would be smooth, and that the market system resulted from the transition would function in a satisfactory fashion unless the government has sufficient fiscal resources at its disposal.

When we argue that state extractive capacity should be maintained and even strengthened in the course of transition, our focus is on the capacity of the central government. In an age of a growing skepticism about the efficacy of central power and central decision-making, it is not fashionable to talk about the virtues of centralization. With no intention to deny the advantages of decentralization, we are nevertheless critical to the currently widespread decentralization fetishism. Just as centralization may have an invisible "ceiling" or upper limit, decentralization may also have a "floor" or a lower limit. If a system is decentralized to the extent that it incapacitates the central government from properly functioning in areas where centralization is unequivocally imperative, then we may say that decentralization has gone too far. Once a certain threshold is crossed, decentralization may engender serious economic and political crises as over-centralization may result in huge efficiency losses. Where does the bottom-line lie?

Apparently, it is not possible to pinpoint exactly where the lower limit of decentralization lies for a specific country at a particular period of time, because countries differ from each other widely in size, population, culture, the form of political system, the stage of economic development, and the level of urbanization, all of which may affect the optimal degree of centralization/ decentralization in a given country. However, if we compare data from a large number of countries for an extended period of time, we may be able to establish a "normal" range of decentralization. Then, if the level of decentralization in a country is found to have fallen below the normal range, we may have reasons to believe that it has crossed the lower threshold. 
Composed of time series data (1973-1992) from 27 countries for which statistics are available, Figures 5 through 8 may help us to gauge the "normal" range of decentralization. These figures show:

1) The ratio of central government revenue to total revenue exceeded $60 \%$ in all but three countries (China, the former Yugoslavia and Canada) (Figure 5).

2) The ratio of central government expenditure to total expenditure exceeded $50 \%$ in all but four countries (China, the former Yugoslavia, Canada and Brazil) (Figure 6).

3) The ratio of central government revenue to GDP exceeded $10 \%$ in all but four countries (China, the former Yugoslavia, Bangladesh, and Peru) (Figure 7).

4) The ratio of central government expenditure to GDP exceeded 10\% again in all but four countries (China, the former Yugoslavia, Bangladesh and Peru) (Figure 8). Bangladesh fell below 10\% only in the beginning of the 70's and Peru fell below $10 \%$ only for one year. Therefore, only China and the former Yugoslavia were the real exceptions.

The four observations are based upon the data of many countries. These countries are different in size, geographical location, cultures, and the stage of economic development. Some are democratic while the others are not; some have federal systems but the others have unitary systems. Despite all these differences, the data presented in Figure 5 through 8 suggest that, in the contemporary world,

(1) A country's central revenue should not fall below $50 \%$ of total government revenue.

(2) A country's central expenditure should not fall below 50\% of total government expenditure.

(3) A country's central revenue should not fall below 10\% of GDP.

(4) A country's central expenditure should not fall below 10\% of GDP. 
If all the four ratios fall below the lower thresholds in a country, then the country can be said to have definitely gone too far in its decentralization. From Figures 5 to 8 , we find that some countries were below the standards only in one or two aspects. These countries might have not really exceeded the lower limit of decentralization. However, when a country falls below all the four thresholds, there is little doubt that it has exceeded the lower limit of decentralization. According to our data, only two countries belong to this category: China and the former Yugoslavia, both of which appear to be exceptions in all the four figures. To arrest the free fall of central extractive capacity, China overhauled its fiscal system at the beginning of 1994. But, the new system has so far not been able to improve the government's revenue buoyancy.

\section{Declining State Extractive Capacity and Its Consequences}

The previous section clearly indicates that China has gone past the lower limit of decentralization. What would happen once a system becomes excessively decentralized? Can the central government still effectively exercise its power? These are the questions this section tries to answer. There is abundant evidence that over-decentralization has significantly weakened the central government's capacity to perform the functions it is supposed to perform, which gave rise to a series of economic, social and political crises. Due to limited space, focus here is placed only on the following issue areas.

\section{Inadequate Provision of Public Goods and Services}

The shortfall of revenue makes it difficult for the Chinese central government to provide adequate national public goods and services. The most conspicuous example is that it can't even afford to finance the country's armed forces.

From Table 1, we can see that, in real term, Chinese military budget has been continuously decreasing between 1978 and 1993, except for 1979 when there was a small-scale war between China and Vietnam. It plummeted to the bottom in 1989. Since 1990, military budget has increased, but it had not been able to exceed

the level of 1978 until 1994.4 As Ellis Joffe rightly points out, "the overriding financial fact in the development of the PLA (the People's Liberation Army) throughout the Deng period has been inadequate funding." 
The shortage of funding resulted in low morale of the military. To compensate for the PLA's budgetary shortfalls, beginning from 1985, the government was compelled to give the PLA a go-ahead to engage itself in various kinds of business activities. The PLA was one of the few armies in the world that set its feet in the business world. However, it has become clear by now that "relying the armed forces to feed themselves" was a bad idea. The military that is engaged in economic activities not only cannot take on the responsibility of protecting the nation and the people, but also might use its monopoly of violence to intervene economy and politics. The military's enthusiasm for money-making has gave rise to serious problems, including rising corruption, worsening civil-military relations, lax discipline, ebbing morale, falling levels of professionalism, widening gaps between coastal and inland units and etc. Alarmed by these dangerous trends, the central leadership finally made decision to take the military out of business in July 1998.

\section{[TABLE 1 ABOUT HERE]}

\section{Deficient Infrastructure}

China's industrial infrastructure in general is deficient. Take railroad and highway transportation. The United States is about the same size as China, but its mileage of railroad is more than five times longer than China's and highway six times longer. If one argues that the United States is not a good comparison for China because it's too advanced, let's look at India. India is at about the same stage of development as China is and has an area of only one third of China. From Table 2, we can see that India's railroad and highway are much longer than China's. The deficiency of railroad and highway has become a bottleneck in China's economic development, which is admitted by both government officials and economists.

There are also local railways and highways that are not national public goods. In the past few years, some provincial governments have made big investment to improve the local conditions of transportation. But because railroads and highways have strong externalities, these governments often try to prevent people from "free-riding" by setting up tollgates to collect use charges. The result is an excessive number of toll posts along these roads, which severely damage the efficient use of them. Although the central government has repeatedly laid injunctions upon local governments to remove these toll posts, the number of toll posts has been on the rise. It is hard for the central government to enforce its regulations because the money used to build the roads is from local funds. 


\section{[TABLE 2 ABOUT HERE]}

\section{$\underline{\text { Deteriorating Environment }}$}

China is developing at the expense of ecological balance and the environment. According to a report by Ecological Environmental Research Center under the Chinese Academy of Science, China's current ecological situation was poor to start with and has been getting worse in the recent years except for some

localized improvements. It asserts that China now faces a dangerous ecological crisis. ${ }^{-7}$ The area affected by acid rain, for instance, has been expanding, from 1.75 million $\mathrm{km}^{2}$ in 1985 to 2.8 million $\mathrm{km}^{2}$ in 1995 . The expansion of acid rain coverage area not only threatens China's economic ecology and the health of its population, but also causes dissatisfaction and protests from such neighboring countries as Japan and Korea.

At the same time as the environment is degenerating, the fund for pollution control has not increased accordingly (see Table 3). Among all kinds of pollution control funds, probably only two, namely, "capital construction fund" and "environmental protection subsidy fund" come from the government budget. "Technical updates and transformation fund" and "retained profits" come from extrabudgetary income and "loans" come from the bank. From Table 3 we can see that governmental budgetary allocations on pollution control accounted for only $0.12 \%$ of GNP in 1985, and since then the ratio has never exceeded the 1985 level. In 1995 it fell to $0.06 \%$. If the central government doesn't make an effort to control pollution and only relies on local governments and enterprises to solve the problem, the worsening of the Chinese environment will bring disastrous results in the near future.

\section{[TABLE 3 ABOUT HERE]}

\section{Growing Inequality}

The decline of central extractive capacity has undermined the central government's redistributive ability. In theory, the central government should have prime responsibility for distribution policies. In the prereform period, the central government did play a pivotal redistributive role in the Chinese economy, extracting large surpluses from rich provinces and making large transfers to poor provinces. The massive fiscal decentralization introduced after 1978, however, significantly reduced the central government's extractive 
capacities. Under the fiscal contract system (caizheng baoganzhi) as practiced between 1980 and 1993, taxes to a great extent were collected and expenditures undertaken on a jurisdiction by jurisdiction basis. Consequently, the ratio of central revenue to GDP quickly shrunk to a level far lower than those in most countries. Under severe fiscal strain, the central government was no longer able to redistribute resources across the country as it preferred. ${ }^{48}$ The explosive growth of funds outside central control has resulted in growing inter-regional, intersectoral, inter-unit, and thereby inter-person inequality.

\section{[TABLE 4 ABOUT HERE]}

Take regional disparity as an example. Table 4 reports average fiscal surplus/GDP (or fiscal deficit/GDP) for China's 30 provinces in four periods. Let's suppose that those provinces that run fiscal surpluses remit all the surpluses to the central government, and that those running fiscal deficits receive central subsidies to balance their budgets. Then Table 4 can tell us how fiscal transfers drained off in the age of decentralization. In the period 1978-80, a half of China's provincial units had financial surpluses. Shanghai then had to turn over to the center a fiscal surplus equivalent to more than 50\% of its GDP; other most developed provinces at the time, such as Beijing, Tianjin, Liaoning, Jiangsu, and Shandong, had to do the same, though to a less degree. Meanwhile, for the 15 deficit provinces, subsidies from the central government could be as high as one-fifth to a quarter of their GDPs. But, after 1980, as the provinces with fiscal surpluses strategically held back their tax effort, their remittance to the central coffer rapidly dwindled. Correspondingly, for poor provinces, the relative size of central subsidies decreased sharply. By the period 1991-93, Shanghai, the richest provincial unit in China, submitted only about $8.5 \%$ of its GDP to the center. Other rich provinces were turning in even less. As a new rich province, Guangdong's contribution to the central coffer, for instance, was barely $0.4 \%$ of its GDP. Consequently, for most of those provinces running deficits in the initial $1978-80$ period, the relative sizes of central subsidies in 1993 were much smaller. As surplus provinces remitted less to the center and deficit provinces received less from the center, the center could no long acted as an effective redistributive agent. As a result, the quality of life for people living in different regions differs a great deal. In this sense, it can be said that the changing extractive capacity of the central government has affected the patterns of regional development in China. The regional gaps are going to persist and even widen unless the center's ability to perform the function of distribution is to be rehabilitated. 


\section{$\underline{\text { Rampant Corruption }}$}

Widespread corruption was an important factor contributing to the social unrest in the late 1980s. Why did corruption become so prevalent? Most scholars believe that the dual track pricing system should take the blame. Another cause of corruption, however, has been largely ignored, that is, the legitimization of what Chinese call "chuangshou" or "creating income" by state agencies.

Facing the mounting fiscal deficit, the central government has found itself increasingly unable to fund state activities fully through budgetary income alone. With funds allocated through budgetary process inadequate to support their routine operation, not to mention providing competitive earnings for their staff, government agencies have become desperate to explore new sources of income. Pinched by money-tight budget, the central government thus was compelled to legitimatize "chuangshou." Army units, police force, courts, hospitals, public libraries, universities, neighborhood committees, tax bureaus, party schools, propaganda departments, and all sorts of party and state agencies were told "if you want more funds for your routine operation and for increasing your staff's bonuses, go out to find money yourselves. " ${ }^{50}$ State agencies turn out to be extremely creative in "making money." Basically, there are three ways for state agencies to make money. First, they may invest in subsidiary companies that operate just like other types of companies in the market. Second, state agencies may use their virtual monopoly of information and bureaucratic distribution networks to speculate on the difference between planned and market prices. Third, they may simply impose ad-hoc charges (tanpai) on individual households and enterprises. "Tanpai" is not only a way for local governments to raise capital for investment but also a vehicle for state agencies at large to increase their operational funds and bonus funds. That is why "tanpai" has run wild in recent years. Instead of seeing furtherance of corporate goals of the state as the best means of maximizing their individual self-interests, Chinese bureaucrats are becoming increasingly dependent on "rents" and therefore increasingly committed to the expansion of "rental havens." As a result, not just individual bureaucrats but also bureaucratic institutions are corrupted. Obviously, the third way of "chuangshou" has nothing to do with the dual pricing system and thereby it would not disappear even if the market reform completely do away with the dual track system. To deal with the problem of corruption, the state thus has to stop "chuangshou" by state agencies. To stop "chuangshou," however, the state has to re-strengthen its extractive capacity. 


\section{Making the State More Effective}

For a government to achieve its desired policy goals, regardless of what those goals may be, it must be able to mobilize requisite resources from the society in the face of resistance by various groups with competing priorities. Without such resources at its disposal, the government may not be able to survive, let alone fulfill its

chosen policy objectives. 1 In general, it can be said that governments with strong extractive capacity are able to pursue their policy goals far more effectively than less capable governments do under similar circumstances. For this reason, we believe that state capacity matters a great deal with regard to development.

Is it possible for the Chinese government to strengthen its extractive capacity? It is possible under two conditions: the ratio of total government to GDP stop falling and the central share of total government revenue begins to increase. Thanks to the 1994 fiscal reform, the central share of total government revenue has increased somewhat. However, the ratio of total government revenue to GDP remains more or less unchanged under the new fiscal system, which means that the ratio of central revenue to GDP is still very low (less than 6\%). Why has the ratio of total government revenue to GDP continued to fall under the new fiscal system? Very simple, the government lost a huge amount of revenues.

There were four major "holes" in the system. The first was tax evasion. Because tax evasion was pervasive, the Chinese government conducted a nationwide tax inspection every year. Table 5 gives the figures for uncovered tax revenues during these annual inspections in the last decade. These figures, of course, represent only the tip of the iceberg. It is estimated that China can collect only $50 \%$ to $75 \%$ of its taxes. $\frac{52}{\text { In }}$ other words, tax evasion costs China more than 200 billion Yuban a year.

\section{[TABLE 5 ABOUT HERE]}

To a large extent, tax evasion was possible because local governments were not serious in enforcing certain tax laws. The collection of personal income tax is a telling example. When this tax was categorized as a shared tax under the pre-1993 system, it had grown very slowly. However, as soon as the tax was re-classified as a local tax in 1994, the revenue from this source soared (see Table 6). The case of personal income tax suggests that local governments' tax effort may be a key factor in understanding the pervasiveness of tax evasion. This 
factor also explains why in 1994 over two-thirds of tax evasion instances involved VAT, a tax from which local governments received only $30 \%$ of collection.

\section{[TABLE 6 ABOUT HERE]}

The second "hole" was unauthorized tax reductions and exemptions. In principle, under the new fiscal system, local governments no longer had right to grant tax breaks and exemptions without the approval of the central government. But some local governments continued past practices. In 1994, Wuhan Municipal Tax Bureau, for instance, circulated within the city a document called "120 Provisions," which permitted local enterprises to enjoy reduced tax rates or even outright tax exemptions. If fully implemented, such local policies could result in a loss of 200 million Yuban in annual tax revenue in the city. ${ }^{5}$ Whan of course was not alone in circumventing the new rules. It was estimated that authorized and unauthorized preferential tax policies together cost the government at least 150 billion Yuban of annual revenue.

The next "hole" in China's current fiscal system was extrabudgetary funds. Since the 1994 reform did not touch extrabudgetary funds, it remained as easy as before for local governments to convert budgetary funds into extrabudgetary funds. Extrabudgetary funds amounted to more than 389 billion Yuban by the end of 1996, double what they had been in 1994 .

In addition to extrabudgetary funds, so-called "extra-extrabudgetary funds" have been growing in recent years. Derived from ad hoc charges, unauthorized fees, forced "contributions," and the like, such funds constitute what Chinese call "little pots of gold (xiaojinku) for the various government agencies that own them. And they are subject to no budgetary control whatsoever. Consequently, no official statistics about such funds are available. By rough estimate, they amounted to 60 to 200 billion Yuban in 1996.58

These four "holes" were different in nature. The first two and the last one were illegal. It was against the law for individuals and enterprises to evade taxes; it was also against the law for local governments to grant tax breaks and exemptions, and to levy fees and charges, without authorization. Under the new fiscal system, rules about these illegal activities are unambiguous. Therefore, in order to plug these "holes," what the central government needs to do is not to introduce new rules but to show resolve in enforcing existing rules. Unfortunately, so far the central government has failed to show such resolve. It is almost unheard of for violators of tax law, such as Wuhan local officials who were responsible for making the illegal "120 Provisions," 
to be sentenced to prison. Without forceful enforcement, no matter how good the rules are in themselves, they are meaningless.

The third "hole," however, was a legitimate one. As long as it is legitimate for local governments to have extrabudgetary funds, it is extremely difficult, if not entirely impossible, for the central government to prevent them from exploiting this loophole. Here, what the government needs to do is to incorporate extrabudgetary funds into the formal system of budgetary accounting.

It is very important to close the four "holes," for they are huge in size. Altogether, they drained the state of 700-1000 billion Yuban of revenues in 1996, which was equivalent to the size of China's total government revenue, or about $11 \%$ of GDP that year. Had the government been able to plug these "holes," its revenue would have instantly increased to more than $20 \%$ of GDP, a level close to that of many developing countries.

To plug these "holes," the central government has to institute rules and norms that provide local governments with incentives to increase their tax efforts rather than behaving opportunistically. Between 1980 and 1993, China fiscal system was characterized by three features:

1. There were rules governing financial flows between the center and provinces, but they were ill defined.

2. Rules governing central-local fiscal relations had no constitutional foundations, which made it possible for the central government unilaterally to change the "rules of the game."

3. Although the center held an extensive discretionary power, it did not possess an effective mechanism to enforce its fiscal policy.

Institutions are supposed to reduce uncertainty in human interactions by limiting the choice set of the actors. The Chinese fiscal system, however, left too much discretionary power to both the central and local governments, which created an institutional environment for opportunism to prevail. Both the central and local governments hoped to reap advantages from opportunism, but each ended up with a shrinking budget (relative to 
GDP). The lesson from this period is that when the rules of the game are ambiguous, unbinding, and not backed by threatened sanctions, they will induce cheating, shirking, opportunism.

To limit the discretionary power of actors and discourage them from acting opportunistically, it is necessary to replace China's old discretion-based fiscal system with a new rule-based system, one in which the "rules" of the game are real rules. For "rules" to be real rules in guiding actors' future courses of action, they have to be unambiguous, binding, and strictly enforced.

(1) Rules have to be unambiguous in specifying the costs and benefits of choices made by all members of the relevant group in all relevant situations. Specifically, rules should be recognizable so that members of the relevant group know what payoffs they should expect from their choices, clear so that proper interpretation is possible, general so that like case are treated alike, inclusive so that no one may avail him- or her- self of loopholes, and non-contingent so that nothing can excuse rule-breakers. A few more words about the last point may be in order. Contingent rules may provide flexibility for actors to respond to unforeseen shocks, but it is difficult to distinguish reacting to a contingency from infringing the rules. Without a clear distinction, rule enforcement may become extremely costly, if not entirely impossible.

(2) Rules are ex ante restrictions that bind the ex post behavior of all parties. The purpose of rules is to define the way the game is played. Therefore, no one in the game should be allowed unilaterally to change these rules after the fact. Economical and political actors' incentives are often not time-consistent. While they may have incentive to accept certain rules, their incentives after the fact are not always compatible with keeping the pledge. Then it would be very tempting for them to revise the rules of the game. For rules to be effective, they have to be able to restrain the ex post behavior of all parties.

(3) Rules would not be binding unless they are enforced in ways that ensure compliance. Although rules can be self-enforcing when it is in everybody's interests to live up to these rules, another method to ensure compliance seems to be more important in most cases: the threat of external sanction. The purpose of such threat is to increase the potential costs of rule-breaking actions, thus making them less attractive. To be successful, the sanction must be sufficient large to reduce the benefit of defection to the point that it is no longer the dominant and preferred strategy, and mechanism must be devised to detect violation, to measure the extent of the violation, and to apprehend the violator. If the sanction is sufficiently large and the enforcement is sufficiently probable, then actors may have to think twice before breaking any rules. In this sense, only with 
enforcement can rules be sustainable. The enforcement power behind the rule is crucial in any institutional design.

China's 1994 fiscal reform was an attempt to replace the old discretion-based system with a rule-based system. Now, the rules of game are much more comprehensive, unambiguous, and transparent; and rule enforcement mechanisms are more reliable. By redefining the choice set of both the central and subnational governments, new institutions greatly limit the space for them to maneuver. Since what used to be within their discretion now becomes unlawful, the costs of defection are higher. Correspondingly, cooperation looks more attractive under the new system than before. China's fiscal reform now seems to be moving in the right direction. However, the institutional arrangements between the central and subnational governments in China are still far from optimal: rules concerning some key aspects of the relationship (e.g., expenditure responsibilities) are still absent; there is still no constitutional constraints that bind the center to follow ex post the rules they make ex ante; huge loopholes continue to be a great drain on state revenue; and enforcement mechanisms rarely put teeth into laws. China still has long way to go to perfect its central-local fiscal relations.

\section{Making the State More Accountable}

Stronger central extractive capacity by itself is no guarantee for China to achieve a higher level of human development. A strong central government is capable of enforcing all kinds of policies, including those exacerbating inequality and sacrificing environment. In addition to enhancing state capacity, therefore, another set of changes is also imperative: re-orienting state preferences.

In the 1980s and early 1990s, the goal of development for Chinese policy-makers was rather narrowly defined. They placed the top priority on rapid aggregate growth. The predominant concern with growth made them no longer willing to sacrifice growth for such goals as equitable distribution of income. For the same reason, environment protection was sidestepped, corruption tolerated, and the construction of new social safety net delayed. Although the government paid a great deal of lip service to education and R\&D, investment in them remained very low as a percentage of GDP. Policy-makers then seemed to believe that, as long as the economy continued to bloom, the prosperity would automatically take care of everything else. China's own experience in the last two decades shows that this assumption is fundamentally flawed. 
It is time for the Chinese government to discard its "growth-first" strategy and embrace instead a broader set of objectives. The expansion of GDP of course is an important means for achieving other objectives, but it is after all a means. The end of development is to improve human welfare. The expansion of GDP may improve human welfare, but it may not. The Twentieth Century has witnessed many instances in which rapid economic growth failed to translate into improvements in the lives of ordinary citizens. Apparently, there is no automatic link between economic growth and human progress.

"Such a link depends on the quality and distribution of economic growth, not only on the quantity of such growth." 62 In terms of quality, if growth comes at the expense of environment, the future generations may lose the opportunity to enjoy the same well being as we do. Thus sustainability must be made an essential component of any sensible development strategy. In terms of distribution, growth by itself cannot ensure that the fruits of economic expansion will be equitably shared. If development is to improve human welfare, then everyone should be able to enjoy the fruits of development, including better nutrition, more secure livelihood, greater access to knowledge and health services, and higher living standards. Therefore, equity must be another essential component of development strategy.

To make development sustainable and equitable, the Chinese government certainly has to change its development strategy. However, "getting the strategy right" is not enough. Changing development strategy without altering the basic political structure cannot guarantee that new strategy will be implemented and that it will not be reversed.

To ensure that the new development strategy will be enacted and implemented, it is extremely important to create an institutional environment in which state policies would not be biased towards any special interests, especially the rich and powerful. This cannot be achieved unless all social groups are given the equal opportunity to participate in policy-making process. For obvious reasons, different groups have different interests. To achieve balanced development, the government should balance their conflicting claims rather than favoring any of them. Thus, in the decision-making process, "participation of the different groups involved in these conflicting claims is a basic necessity." ${ }^{63}$ A system of decision-making that allows broad participation can best resist pressure from the economically powerful. Moreover, when the voices of all those involved are heard in the corridors of power, the government will become more accountable and transparent, and their policies will less likely undergo sudden and precipitant changes. 


\section{Conclusion}

China is in the process of the transition from a command economy to a market economy. The transition, by definition, aims at gradually establishing the market as the central mechanism of resource allocation. In the course of transition, however, we should avoid what Galbraith calls "simplistic ideology."

what Przeworski calls "neoliberal fallacy," The market is not a panacea for solving all our socioeconomic problems. Nor is it a neutral, natural, apolitical, and ahistorical institution. Moreover, the market is not an end in itself. Rather, it is just a means to promote social and individual welfare. For this reason, the potential role of non-market means, including state intervention, in improving welfare should be neither dismissed nor underestimated. This essay argues that active state engagement is indispensable for facilitating both market transition and economic development, two items high on China's agenda. Even China one day becomes a mature market economy, state interventions are still needed to correct pervasive market failures and make efforts to further promote human development. Efficient market operation cannot be attained without government intervention.

All governments intervene in economy by default or design. Contrary to neoclassical theory, in real world, less government intervention doesn't always produce higher level of welfare for people. As many comparative studies have shown, it is in those countries where governments have played active roles that economic structural adjustment has been swifter, international competitiveness stronger, growth more sustained, and distribution of income and wealth more equal.

The fact that there may exist government policies that would be welfare improvements, of course, does not necessarily support a presumption that government intervention is always desirable. Markets fail, but so do governments. Therefore, we should not give a blanket endorsement of indiscriminate state interventions.

Especially, in the course of the transition from a command economy to a market economy, the role of the state needs to be redefined and governance needs to be improved. The redefinition involves two changes. First, the range of state intervention should be narrowed. The state should concentrate its attention to macroeconomic issues and human development issues while leaving microeconomic decisions to individual economic agents. Second, policy instruments need to be changed. Rather than relying on administrative commands, the government should try to affect production activity mainly through fiscal and monetary policies and regulatory 
policies. Governance can be improved by strengthening state capacity and increasing openness in the process of policy-making and implementation.

The purpose of the essay is not to justify state intervention, but to argue against market utopianism.

The central fallacy in the market utopianism is that the market and the state are necessarily separate and ever antagonistic, and that former is benevolent and the latter not. We should refuse to pose the question as a simple choice between the market mechanism and state intervention. Evidence from the cases of successful development suggests that when the state and market mechanism in tandem, when they play complementary roles, the whole is greater than the sum. The wisdom thus lies in pragmatically developing a mutually supportive structure of market and non-market institutions. 
Table 1. Chinese Military Budget (1978--1993)

\section{(billion Yuban)}

\begin{tabular}{|c|c|c|c|c|}
\hline Year & Price Index & Nominal & Real Expenditure & MB Index \\
\hline & $1978=1.00$ & Expenditure & & $1978=1.00$ \\
\hline 1978 & 1.00 & 16.784 & 16.784 & 1.00 \\
\hline 1979 & 1.02 & 22.266 & 21.829 & 1.30 \\
\hline 1980 & 1.08 & 19.384 & 179.32 & 1.07 \\
\hline 1981 & 1.11 & 16.797 & 15.173 & 0.90 \\
\hline 1982 & 1.13 & 17.635 & 15.634 & 0.93 \\
\hline 1983 & 1.15 & 17.713 & 15.470 & 0.92 \\
\hline 1984 & 1.18 & 18.076 & 15.358 & 0.92 \\
\hline 1985 & 1.28 & 19.153 & 14.952 & 0.89 \\
\hline 1986 & 1.36 & 20.075 & 14.783 & 0.88 \\
\hline 1987 & 1.46 & 20.962 & 14.387 & 0.86 \\
\hline 1988 & 1.73 & 21.800 & 12.630 & 0.75 \\
\hline 1989 & 2.03 & 25.147 & 12.363 & 0.74 \\
\hline 1990 & 2.08 & 29.031 & 13.977 & 0.83 \\
\hline 1991 & 2.14 & 33.031 & 15.457 & 0.92 \\
\hline 1992 & 2.25 & 37.790 & 16.781 & 1.00 \\
\hline 1993 & 2.55 & 42.580 & 16.698 & 0.99 \\
\hline 1994 & 3.10 & 55.071 & 17.765 & 1.06 \\
\hline 1995 & 3.56 & 63.672 & 17.885 & 1.07 \\
\hline 1996 & 3.78 & 72.006 & 19.049 & 1.13 \\
\hline 1997 & 3.81 & 81.257 & 21.327 & 1.27 \\
\hline
\end{tabular}

Source: State Statistics Bureau, Chinese Statistics Yearbook 1997, p. 267. 
Table 2. Railroad and Highway in China, India and US (km)

$\begin{array}{ccc} & \text { Railroad } & \text { Highway } \\ \text { China } & 54,000(1990) & 1,029,000(1990) \\ \text { India } & 61,850(1986) & 1,970,000(1989) \\ \text { US } & 270,312(1991) & 6,365,590(1991)\end{array}$

Source: CIA, The World Factbook, 1992, p.22,156,359 
Table 3. Pollution Control Funds 1985--1993

\section{(Billion Yuban)}

$\begin{array}{ccccccccc} & \mathbf{1} & \mathbf{2} & \mathbf{3} & \mathbf{4} & \mathbf{5} & \mathbf{6} & \mathbf{1 / G N P} & \mathbf{7 / G N P} \\ 1985 & 2.21 & 0.51 & 0.49 & 0.06 & 0.06 & 0.32 & 0.26 \% & 0.12 \% \\ 1988 & 4.25 & 0.96 & 0.66 & 1.21 & 0.01 & 0.83 & 0.30 \% & 0.12 \% \\ 1989 & 4.35 & 0.95 & 0.63 & 1.46 & 0.11 & 0.75 & 0.27 \% & 0.09 \% \\ 1990 & 4.54 & 0.09 & 0.68 & 1.34 & 0.11 & 0.75 & 0.26 \% & 0.04 \% \\ 1991 & 5.97 & 1.40 & 1.02 & 0.72 & 0.21 & 0.56 & 0.30 \% & 0.12 \% \\ 1992 & 6.47 & 1.40 & 1.09 & 1.79 & 0.22 & 0.60 & 0.27 \% & 0.10 \% \\ 1993 & 6.93 & 1.31 & 1.07 & 2.09 & 0.32 & 0.62 & 0.22 \% & 0.08 \% \\ 1994 & 8.34 & 1.88 & 1.03 & 2.48 & 0.33 & 0.60 & 0.18 \% & 0.06 \%\end{array}$

Note: 1 , Total; 2, "capital construction fund"; 3, "environmental protection subsidy fund"; 4, "technical updates and transformation fund"; 5, "retained profits"; 6, "loans"; and 7, 2+3.

Source: State Statistics Bureau, Chinese Statistics Yearbook 1993, p.822; Chinese Statistics Yearbook 1996, p.742. 


\section{Table 4}

Provincial Fiscal Surplus/GDP, 1978-1993 (\%)

\begin{tabular}{|c|c|c|c|c|}
\hline Region & 1978-80 & 1981-85 & $1986-90$ & $1991-93$ \\
\hline BEIJING & 25.63 & 14.29 & 3.54 & 1.05 \\
\hline TIANJIN & 26.33 & 16.20 & 5.83 & 3.85 \\
\hline HEBEI & 6.00 & 2.38 & -0.21 & 0.10 \\
\hline SHANXI & -0.28 & -0.95 & -2.28 & -0.82 \\
\hline INNER MONGOLIA & -20.77 & -15.94 & -11.12 & -7.14 \\
\hline LIAONING & 22.38 & 11.50 & 2.68 & 0.99 \\
\hline JILIN & -2.88 & 4.72 & -5.74 & -3.66 \\
\hline HEILONGJIANG & -7.33 & -3.41 & -2.51 & -1.71 \\
\hline SHANGHAI & 51.07 & 38.68 & 17.26 & 8.54 \\
\hline JIANGSU & 11.26 & 9.09 & 3.34 & 1.37 \\
\hline ZHEJIANG & 6.98 & 6.84 & 3.16 & 2.03 \\
\hline ANHUI & 3.17 & 1.19 & -0.90 & -2.30 \\
\hline FUJIAN & -1.38 & -2.19 & -2.47 & -0.93 \\
\hline JIANGXI & 4.48 & -2.73 & -3.51 & -2.82 \\
\hline SHANDONG & 10.18 & 4.39 & -0.81 & -0.01 \\
\hline HENAN & 2.65 & 1.45 & -1.06 & -0.61 \\
\hline HUBEI & 2.19 & 4.09 & -0.09 & -0.30 \\
\hline HUNAN & 3.23 & 2.01 & -1.12 & -0.56 \\
\hline GUANGDONG & 4.76 & 1.38 & -0.66 & 0.38 \\
\hline GUANGXI & -7.97 & 4.20 & -5.97 & -2.25 \\
\hline HAINAN & -3.14 & -5.12 & -7.75 & -5.87 \\
\hline SICHUAN & 0.50 & 0.43 & -1.50 & -0.84 \\
\hline GUIZHOU & -11.70 & -8.04 & -6.30 & -3.34 \\
\hline YUNNAN & -9.71 & -5.07 & -5.89 & -1.19 \\
\hline TIBET & NA & -61.60 & -50.83 & -49.64 \\
\hline
\end{tabular}




$\begin{array}{lcccc}\text { SHAANXI } & -1.24 & -3.72 & -3.85 & -2.44 \\ \text { GANSU } & 6.56 & -3.36 & -5.61 & -3.83 \\ \text { QINGHAI } & \text { NA } & -25.59 & -16.20 & -11.57 \\ \text { NINGXIA } & -22.01 & -23.03 & -17.57 & -10.17 \\ \text { XINJIANG } & -24.15 & -18.17 & -11.72 & -7.02\end{array}$

Source: Ministry of Finance, China Public Finance Yearbook, various year. 
Table 5: Uncovered Tax Revenue, 1985-1996

(Billion Yuan)

1985-1992

90.1
1993

12.7

\section{4}

20.4
1995

1996

22.7

22.4

Source: Xinhua News Agency, Beijing, July 13, 1993; March 22, 1995; May 17, 1996; China News Agency, Beijing, May 28, 1997. 
Table 6: Growth Index of Personal Income Tax, 1993-1996

(The same period of the last year as 100)

1994

1995

1996

$1996^{b}$

154.90

180.25

158.90

151.9

Note: a The first three months of 1996. ${ }^{b}$ The first eight months of 1996

Source: Shaoguang Wang, "China's 1994 Fiscal Reform: An Initial Assessment." 


\section{REFERENCES}

Alesina, A. and Rodrik, D. 1992. "Distribution, Political Conflict, and Economic Growth," in Cukierman, A., Hercowitz, Z., and Leiderman, L., eds., Political Economy, Growth, and Business Cycles. (Cambridge: MIT Press, 1992), pp. 23-50.

Amsden, Alice. 1989. Asia's Next Giant: South Korea and Late Industrialization (New York: Oxford University Press).

An, Tifu. 1992. "Guanyu zhenxing woguo caizheng di ruogan sikao" [Reflections on How to Enhance Our Public Finance], Caijing yanjiu [Journal of Public Finance], no. 1 (1992), pp. 8-16.

An, Tifu and Liang Peng. 1996. "Dangqian zhong guo caizheng: xingshi, wenti, he duiche" [The Contemporary Chinese Public Finance: The Situation, Problems, and Solutions]. Caizheng yanjiu [Studies in Public Finance], no. 7, pp. 15-19.

Arndt, Heinz W. 1988. "'Market Failure' and Underdevelopment." World Development, vol. 16, no. 2, pp. 219229.

Arrow, Kenneth J. 1987. "Rationality of Self and Others in an Economic System." In Robin M. Hograth and Melvin W. Reder, eds., Rational Choice: The Contrast Between Economics and Psychology (Chicago: University of Chicago Press).

Averch, Harvey. 1990. Private Markets and Public Intervention: A Primer for Policy Designers (Pittsburgh: University of Pittsburgh Press).

Bardhan, Pranab. 1990. "Symposium on the State and Economic Development." Journal of Economic Perspectives, vol. 4, no. 3 .

Baumol, W.J., Panzar, J. and Willig, R. 1982. Contestable Markets and the Theory of Industry Structure (New York: Harcourt Brace Janovich).

Boadway, Robin W. 1989. "The Role of Government in a Market economy," in Warren J. Samuels, ed., Fundamentals of the Economic Role of Government (New York: Greenwood Press).

Chaudhry, Kiren Aziz. 1993. "The Myths of the Market and the Common History of Late Developers," Politics and Society, vol. 21, no. 2.

Chinese Science Academy. 1990. Guoqing yu Juece [National Conditions and policymaking] (Beijing: Beijing Publishing Company). 
Cong, Ming. 1996. "Guanyu woguo zhongchangqi zhengxing caizheng de jige wenti" [Issues Concerning How to Strengthen China's Public Finance in Medium- and Long-Term]. Caimao jingji [Financial Economics], no. 6 , pp. $15-21$.

Das, Dilip K. 1992. "The Invisible Hand versus the Visible Hand: The Korean Case," Seoul Journal of Economics, vol. 5, no. 2 .

Day, Richard H. 1993. "Bounded Rationality and the Convolution of Market and State," in Richard H Day, Gunnar Eliasson and Clas Wihlborg, eds., The Markets for Innovation, Ownership and Control (Amsterdam: North-Holland).

Ding, Si. 1996. "Zhengxing caizheng shuoxianyao tongyi caizheng" [To Boost Public Finance, Public Finance Has To Be Unified First]. Yunnan caizheng yu kuaiji [Yunnan Public Finance and Accounting], no. 11, pp. 9-14.

Evans, Peter B. 1989. "Predatory, Developmental, and Other Apparatuses: A Comparative Political Economy Perspective on the Third World State," Sociological Forum, vol. 4, no. 4.

Galbraith, John K. 1990. "Revolt in Our Time: The Triumph of Simplistic Ideology," in Gwyn Prins, ed., Spring in Winter: The 1989 Revolutions (Manchester: Manchester University Press, 1990).

Gao, Shangquan. 1993. "Taking a Market-oriented Direction and Pushing forward in a gradual Way: A Basic Experience of China's Economic Reform," a paper presented to International Symposium on the Theoretical and Practical Issues of the Transition toward the Market Economy in China. Hainan, China. Garnaut, Ross. 1991. "The Market and the State in Economic Development: Applications to the International Trading System," The Singapore Economic Review, vol. 26, no. 2, 13-26.

Gerschenkron, Alexander. 1962. Economic Backwardness in Historical Perspective(Cambridge, MA: Harvard University Press).

Goodrich, Carter. 1968. "State In, State Out: A Pattern of Development Policy," Journal of Economic Issues, no. 2, pp. $365-383$.

Greenwald, Bruce and Joseph E. Stiglitz. 1986 "Externalities in Economies with Imperfect Information and Incomplete Markets," Quarterly Journal of Economics, no. 90.

Haq, Mahbub ul. 1995. Reflections on Human Development (New York: Oxford University Press). Herschler, Stephen B. 1995. "The 1994 Tax Reforms: The Center Strikes Back." China Economic Review, Vol. 6, No. 2: 239-245. 
Hirschman, Albert O. 1958. The Strategy of Economic Development (New Haven: Yale University Press). Jiang, Xiaojuan. 1993a. "Shichang Yunzhuan Yu Zhengfu Zhineng Zhuanhuan" [The Operational Efficiency of the Market and the Changes of Government Functions], Gaige [Reform], no. 1, pp. 62-67.

----- 1993b. "Zhongguo Tuixing Chanye Zhengce Zhongde Gonggong Xianze Wenti" [Public Choice Issues in China’s Industrial Policies], Jingji Yanjiu [Researches in Economics], no. 6, pp. 3-18.

Joffe, Ellis. 1994. "The PLA and the Economy: The Effects of Involvement," a paper presented at IISS/CAPS conference "Chinese Economic Reform: The Impact on Security Policy," Hong Kong, 8-10 July 1994. Johnson, Chalmers. 1982. MITI and the Japanese Miracle: The Growth of Industrial Policy, 1925-1975 (Stanford: Stanford University Press).

Katzenstein, Peter, ed. 1978. Between Power and Plenty (Madison: The University of Wisconsin Press).

Kornai, Janos. 1992. "The Post-socialist Transition and the State: Reflection in the Light of Hungarian Fiscal Problems," American Economic Review, vol. 82, no. 2.

Krueger, Anne O. 1990. "Government Failure in Development," Journal of Economic Perspectives, vol. 4, no. 3, pp. 9-23.

Lazonick, William. 1991. Business Organization and the Myth of the Market Economy (New York: Cambridge University Press).

Leibenstein, H. 1978. General X-Efficiency Theory and Economic Development (New York: Oxford University Press).

Levi, Margaret. 1988. Of Rule and Revenue, (Berkeley: University of California Press).

Li, Chengrui, and Liu Cheng. 1997. "Dangqian quanshehui ziji yunxing mianning de kunjing yu chulu" [Problems in the Circulation of Total Social Funds and Possible Solutions], Jingji yanjiu cankao [Reference Materials in Economic Research], no. 1007, pp. 2-19.

Lie, John. 1993. "Visualizing the Invisible Hand: The Social Origins of 'Market Society' in England, 15501750," Politics and Society, vol. 21, no. 3.

Liu, Zhongli. 1995. "Zhenxing guojia caizheng shenhua caishui gaige" [Deepening Fiscal Reform and Revitalizing Public Finance]. Zhongguo caijing bao [Chinese Public Finance Daily]. December 7. Ministry of Finance. 1997. Zhongguo caizheng nianjian 1997 [China Public Finance Yearbook] (Beijing: China Public Finance Press). 
Musgrave, Richard A. 1981. "Leviathan Cometh-Or Does He?" in H Ladd and T Tideman, eds., Tax and Expenditure Limitation (Washington, D.C.: The Urban Institute Press).

Okimoto, Daniel I. 1989. Between MITI and the Market: Japanese Industrial Policy for High Technology (Stanford: Stanford University Press).

Okun, Arthur. Equality and Efficiency: The Big Tradeoff, (Washington, D.C.: Brookings Institution, 1975).

Perotti, Roberto. 1996. "Growth, Income Distribution, and Democracy: What the Data Say," Journal of Economic Growth, vol. 1 (June 1996), pp. 149-187.

Persson, T. Tabellini, G. 1994. "Is Inequality Harmful for Growth?" American Economic Review, vol. 84, pp. 600-621.

Polanyi, Karl. 1957. The Great Transformation (Boston: Beacon Press).

Przeworski, Adam. 1991. Democracy and the Market: Political and Economic Reforms in Eastern Europe and Latin America, (Cambridge University Press).

1992. "The Neoliberal Fallacy," Journal of Democracy, vol. 3, no. 3, pp. 45-59.

Sabel, Charles F. 1993. "Learning by Monitoring: The Institutions of Economic Development," unpublished paper, MIT

Sen, Amartya. 1996. "Social Commitment and Democracy: The Demands of Equity and Financial Conservatism." In Paul Barker, ed., Living as Equals (New York: Oxford University Press), pp. 9-38.

Shapiro, Helen and Lance Taylor. 1990. "The State and Industrial Strategy," World Development, vol. 18, no. 6. Sheng, Hong. 1992. "Tuidong Woguo Zhengzai Jingli Zhedi TiZhi Bianqian” [Pushing the On-going Institutional Changes Forward], Jingji Yanjiu [Researches in Economics], no. 5.

Stiglitz, Joseph E. 1986. Economics of the Public Sector (New York: Norton). -1989. The Economic Role of the State (Oxford: Basil Blackwell).

-------1991a. "The Invisible Hand and Modern Welfare Economics," NBER Working Paper \# 3641.

--------1991b. "Government, Financial Markets, and Economic Development," NBER Working Paper \# 3669.

-------1998a. "More Instruments and Broader Goals: Moving Toward the Post-Washington Consensus," the 1998 WIDER Annual Lecture, Helsinki, Finland, January 7.

--------1998b. " Distribution, Efficiency and Voice," a manuscript, World Bank, July 14, 1998.

Thompson, E. P. 1971. "The Moral Economy of the English Crowd in the Eighteenth Century," Past and Present, no. 50. 
UNCTD(United Nations Conference on Trade and Development). 1998. "Income Distribution, Capital Accumulation, and Growth," Challenge, vol. 41, no. 2 (March/April 1998), pp. 61-80.

Wade, Robert. 1991. Governing the Market: Economic Theory and the Role of Government in East Asian Industrialization (Princeton: Princeton University Press).

Wang Shaoguang. 1996. "The Institutional Roots of Central-Local Rivalry: China, 1980-1996," in Chong-Pin Lin, ed., PRC Tomorrow: Development under the Ninth Five-Year Plan (Taipei: National Sun Yat-sen University), pp. 1-40.

-----1997a. "China's 1994 Fiscal Reform: An Initial Assessment," Asian Survey, vol. XXXVII, no. 9 (September), pp. 801-17.

------1997b. "The Institutional Sources of Central-Local Rivalry: 1980-1993," manuscript, Yale University.

------1998. "The Military Expenditure of China, 1989-1998," SIPRI Yearbook 1999 (New York: Oxford University Press, 1999), 334-349.

Wang Shaoguang and Hu Angang. 1999. The Political Economy of Uneven Development in China (Armonk: M.E.Sharpe).

White, Gordon, ed. 1988 Developmental States in East Asia (London: Macmillan).

World Bank. 1991. World Development Report (Washington, D.C.: World Bank).

Xu Yi and He Shengmin. 1995. "Dui dangqian caizheng jingji xingshi de jidian kaifa he jianyi" [Comments on the Current Situation of Public Finance]. Jingji gaige yu fazhan [Economic Reform and Development]. no. 8 .

Yu Tianyi. 1995. "Guoyou zhichan liushi wenti fenxi" [An Analysis of the Causes of State Property Loss]. Jingji yu shehui [Economy and Society], no. 5: 45-48.

Zysman, John. 1983. Government, Markets, and the Growth (Ithaca: Cornell University Press). 


\section{ENDNOTES}

\footnotetext{
${ }^{1}$ Hong Sheng, "Tuidong Woguo Zhengzai Jingli Zhedi TiZhi Bianqian” [Pushing the On-going Institutional Changes Forward], Jingji Yanjiu [Researches in Economics], no. 5 (1992); Xiaojuan Jiang, "Shichang Yunzhuan Yu Zhengfu Zhineng Zhuanhuan" [The Operational Efficiency of the Market and the Changes of Government Functions], Gaige [Reform], no. 1 (1993), pp. 62-67; "Zhongguo Tuixing Chanye Zhengce Zhongde Gonggong Xianze Wenti" [Public Choice Issues in China’s Industrial Policies], Jingji Yanjiu [Researches in Economics], no. 6 (1993), pp. 3-18.
}

${ }^{2}$ Anne O Krueger, "Government Failure in Development," Journal of Economic Perspectives, vol. 4, no. 3 (1990), pp. 16-17.

${ }^{3}$ W.J. Baumol, J. Panzar, and R. Willig, Contestable Markets and the Theory of Industry Structure (New York: Harcourt Brace Janovich, 1982).

${ }^{4}$ Joseph E. Stiglitz, "The Invisible Hand and Modern Welfare Economics," NBER Working Paper \# 3641 (1991).

${ }^{5}$ Joseph E. Stiglitz, Economics of the Public Sector (New York: Norton, 1986 ).

${ }^{6}$ Heinz W. Arndt, "'Market Failure' and Underdevelopment." World Development, vol. 16, no. 2 (1988).

${ }^{7}$ Kenneth J. Arrow, "Rationality of Self and Others in an Economic System." In Robin M. Hograth and Melvin W. Reder, eds., Rational Choice: The Contrast Between Economics and Psychology (Chicago: University of Chicago Press, 1987), p. 208.

${ }^{8}$ Stiglitz, Economics of the Public Sector.

${ }^{9}$ Bruce Greenwald, and Joseph E. Stiglitz, "Externalities in Economies with Imperfect Information and Incomplete Markets," Quarterly Journal of Economics, no. 90 (1986).

${ }^{10}$ Robin W. Boadway, "The Role of Government in a Market economy," in Warren J. Samuels, ed., Fundamentals of the Economic Role of Government (New York: Greenwood Press, 1989).

${ }^{11}$ Joseph E. Stiglitz, The Economic Role of the State (Oxford: Basil Blackwell, 1989).

${ }^{12}$ World Bank, World Development Report 1991 (Washington, D.C.: World Bank, 1991); A. Alesina, and D. Rodrik, "Distribution, Political Conflict, and Economic Growth," in Cukierman, A., Hercowitz, Z., and Leiderman, L., eds., Political Economy, Growth, and Business Cycles. (Cambridge: MIT Press, 1992), pp. 2350; T. Persson and G. Tabellini, 1994. "Is Inequality Harmful for Growth?" American Economic Review, Vol. 
84 (1994), pp. 600-621; Roberto Perotti, "Growth, Income Distribution, and Democracy: What the Data Say," Journal of Economic Growth, Vol. 1 (June 1996), pp. 149-187; UNCTD(United Nations Conference on Trade and Development), "Income Distribution, Capital Accumulation, and Growth," Challenge, Vol. 41, No. 2 (March/April 1998), pp. 61-80.

${ }^{13}$ Richard H. Day, "Bounded Rationality and the Convolution of Market and State," in Richard H Day, Gunnar Eliasson and Clas Wihlborg, eds., The Markets for Innovation, Ownership and Control (Amsterdam: NorthHolland, 1993).

${ }^{14}$ World Bank, World Development Report 1991.

${ }^{15}$ Kiren Aziz Chaudhry, "The Myths of the Market and the Common History of Late Developers," $\underline{\text { Politics and }}$ Society, vol. 21, no. 2 (1993).

${ }^{16}$ Ross Garnaut, "The Market and the State in Economic Development: Applications to the International Trading System," The Singapore Economic Review, vol. 26, no. 2 (1991).

17 Ibid.

${ }^{18}$ Arndt, "'Market Failure' and Underdevelopment."

${ }^{19}$ E. P. Thompson, "The Moral Economy of the English Crowd in the Eighteenth Century," Past and Present, no. 50 (1971).

${ }^{20}$ Chaudhry, "The Myths of the Market and the Common History of Late Developers."

${ }^{21}$ John Lie, "Visualizing the Invisible Hand: The Social Origins of 'Market Society' in England, 1550-1750," Politics and Society, vol. 21, no. 3 (1993).

${ }^{22}$ Adam Przeworski, Democracy and the Market: Political and Economic Reforms in Eastern Europe and Latin America, (Cambridge University Press, 1991), p. 161.

${ }^{23}$ Karl Polanyi, The Great Transformation (Boston: Beacon Press, 1957), p. 157.

${ }^{24}$ Garnaut, "The Market and the State in Economic Development."

${ }^{25}$ Arndt, "'Market Failure' and Underdevelopment."

26 Ibid.

${ }^{27}$ H. Leibenstein, General X-Efficiency Theory and Economic Development (New York: Oxford University Press, 1978).

${ }^{28}$ Arndt, "'Market Failure' and Underdevelopment," p. 228. 
${ }^{29}$ William Lazonick, Business Organization and the Myth of the Market Economy (New York: Cambridge

University Press, 1991), p. 7.

${ }^{30}$ Stiglitz, The Economic Role of the State.

${ }^{31}$ Helen Shapiro, and Lance Taylor, "The State and Industrial Strategy," World Development, vol. 18, no. 6 (1990).

${ }^{32}$ Carter Goodrich, "State In, State Out: A Pattern of Development Policy," Journal of Economic Issues, no. 2 (1968), pp. 365-383.

${ }^{33}$ Alexander Gerschenkron, Economic Backwardness in Historical Perspective (Cambridge, MA: Harvard University Press, 1962).

${ }^{34}$ Lazonick, Business Organization and the Myth of the Market Economy.

${ }^{35}$ Harvey Averch, Private Markets and Public Intervention: A Primer for Policy Designers (Pittsburgh: University of Pittsburgh Press, 1990).

${ }^{36}$ Lazonick, Business Organization and the Myth of the Market Economy.

${ }^{37}$ Averch, Private Markets and Public Intervention: A Primer for Policy Designers.

${ }^{38}$ Shapiro and Taylor, "The State and Industrial Strategy."

${ }^{39}$ Charles F. Sabel, "Learning by Monitoring: The Institutions of Economic Development," unpublished paper, MIT, 1993.

${ }^{40}$ Joseph E. Stiglitz, "More Instruments and Broader Goals: Moving Toward the Post-Washington Consensus," the 1998 WIDER Annual Lecture, Helsinki, Finland, January 7, 1998.

${ }^{41}$ Alice Amsden, Asia's Next Giant: South Korea and Late Industrialization (New York: Oxford University Press, 1989); Robert Wade, Governing the Market: Economic Theory and the Role of Government in East Asian Industrialization (Princeton: Princeton University Press, 1991); Gordon White, ed., Developmental States in East Asia (London: Macmillan, 1988).

42 The "debt income" in the Chinese budgetary data has already been subtracted so that the data are comparable to those of other countries.

${ }^{43}$ Shaoguang Wang, "China's 1994 Fiscal Reform: An Initial Assessment," Asian Survey, Vol. XXXVII, No. 9 (September 1997), pp. 801-17.

44 There are other sources of defense-related expenditures, but they are generally beyond the direct control of the PLA. For the PLA, the official defense budget is the only budgetary allocation it gets from the government. 
${ }^{45}$ Ellis Joffe, "The PLA and the Economy: The Effects of Involvement," a paper presented at IISS/CAPS conference "Chinese Economic Reform: The Impact on Security Policy," Hong Kong, 8-10 July 1994.

${ }^{46}$ Shaoguang Wang, "The Military Expenditure of China, 1989-1998," SIPRI Yearbook 1999 (New York:

Oxford University Press, 1999), 334-349.

${ }^{47}$ Chinese Science Academy, Guoqing yu Juece [National Conditions and PolicyMaking] (Beijing: Beijing Publishing Company, 1990).

48 Shaoguang Wang, "The Institutional Roots of Central-Local Rivalry: China, 1980-1996," in Chong-Pin Lin, ed., PRC Tomorrow: Development under the Ninth Five-Year Plan (Taipei: National Sun Yat-sen University, 1996), pp. 1-40.

${ }^{49}$ Shaoguang Wang and Angang Hu, The Political Economy of Uneven Development in China (Armonk: M.E.Sharpe, 1999).

${ }^{50}$ Tifu An, "Guanyu zhenxing woguo caizheng di ruogan sikao," Caijing yanjiu No. 1 (1992), pp. 8-16.

51 Margaret Levi, Of Rule and Revenue, Berkeley: University of California Press, 1988.

${ }^{52}$ Si Ding, "Zhengxing caizheng shuoxianyao tongyi caizheng" [To Boost Public Finance, Public Finance Has To Be Unified First]. Yunnan caizheng yu kuaiji [Yunnan Public Finance and Accounting], No. 11, pp. 9-14 (1996); Zhongli Liu, "Zhenxing guojia caizheng shenhua caishui gaige" [Deepening Fiscal Reform and Revitalizing Public Finance]. Zhongguo caijing bao [Chinese Public Finance Daily]. December 7, 1995. ${ }^{53}$ Tifu An, and Peng Liang, "Dangqian zhong guo caizheng: xingshi, wenti, he duiche" [The Contemporary Chinese Public Finance: The Situation, Problems, and Solutions]. Caizheng yanjiu [Studies in Public Finance], No. 7 (1996), pp. 15-19.

${ }^{54}$ Xinhua News Agency, Beijing, March 22, 1995.

${ }^{55}$ Stephen B. Herschler, "The 1994 Tax Reforms: The Center Strikes Back." China Economic Review, Vol. 6, No. 2 (1995): 239-245.

${ }^{56}$ Tianyi Yu, "Guoyou zhichan liushi wenti fenxi" [An Analysis of the Causes of State Property Loss]. Jingji yu shehui [Economy and Society], No. 5 (1995): 45-48; Ming Cong, "Guanyu woguo zhongchangqi zhengxing caizheng de jige wenti" [Issues Concerning How to Strengthen China's Public Finance in Medium- and LongTerm]. Caimao jingji [Financial Economics], No. 6 (1996), pp. 15-21.

${ }^{57}$ Ministry of Finance, Zhongguo caizheng nianjian 1997 [China Public Finance Yearbook] (Beijing: China Public Finance Press, 1997). 
${ }^{58}$ Si Ding, "Zhengxing caizheng shuoxianyao tongyi caizheng" [To Boost Public Finance, Public Finance Has To Be Unified First], Yunnan caizheng yu kuaiji [Yunnan Public Finance and Accounting], No. 11 (1996), pp. 9-14; Yi Xu and Shengmin He, "Dui dangqian caizheng jingji xingshi de jidian kaifa he jianyi" [Comments on the Current Situation of Public Finance], Jingji gaige yu fazhan [Economic Reform and Development]. No. 8 (1995); Chengrui Li,, and Cheng Liu, "Dangqian quanshehui ziji yunxing mianning de kunjing yu chulu"

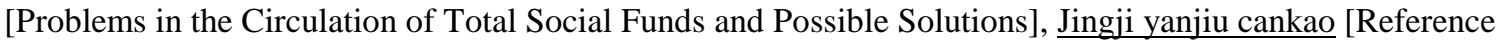
Materials in Economic Research], No. 1007 (1997), pp. 2-19.

59 In August 1996, the central government overhauled extrabudgetary funds. Thirteen major categories of extrabudgetary funds were re-classified as budgetary funds.

${ }^{60}$ Shaoguang Wang, "The Institutional Sources of Central-Local Rivalry: 1980-1993," manuscript, Yale University, 1998.

${ }^{61}$ Shaoguang Wang, "China's 1994 Fiscal Reform: An Initial Assessment," Asian Survey, Vol. XXXVII, No. 9 (September 1997), pp. 801-17.

${ }^{62}$ Mahbub ul Haq, Reflections on Human Development (New York: Oxford University Press, 1995), p. 15.

${ }^{63}$ Amartya Sen, "Social Commitment and Democracy: The Demands of Equity and Financial Conservatism," in Paul Barker, ed., Living as Equals (New York: Oxford University Press, 1996), p. 21.

${ }^{64}$ Joseph E. Stiglitz, " Distribution, Efficiency and Voice," a manuscript, World Bank, July 14, 1998.

${ }^{65}$ John K. Galbraith, 1990. "Revolt in Our Time: The Triumph of Simplistic Ideology," in Gwyn Prins, ed., Spring in Winter: The 1989 Revolutions (Manchester: Manchester University Press, 1990).

${ }^{66}$ Adam Przeworski, "The Neoliberal Fallacy," Journal of Democracy (1992).

${ }^{67}$ Janos Kornai, "The Post-socialist Transition and the State: Reflection in the Light of Hungarian Fiscal Problems," American Economic Review, vol. 82, no. 2 (1992).

${ }^{68}$ White, Developmental States in East Asia; Peter Katzenstein, ed., Between Power and Plenty (Madison: The University of Wisconsin Press, 1978); Chalmers Johnson, MITI and the Japanese Miracle: The Growth of Industrial Policy, 1925-1975 (Stanford: Stanford University Press, 1982); John Zysman, Government, Markets, and the Growth (Ithaca: Cornell University Press, 1983). 